\title{
Effect of Effluent from Biodigestion of Pre-Treated Rice Bran and Animal Manure on the Dry Matter Yield and Nutrient Uptake of Amaranthus viridis
}

\author{
Oluwakemi Florence 0joㄹ, Gbolabo Abidemi Ogunwande ${ }^{2}$, Olusola Olajumoke Adesanwo ${ }^{3}$, \\ Francis Tope Olatoberu ${ }^{3 *}$
}

${ }^{1}$ Institute of Ecology and Environmental Studies, Faculty of Science, Obafemi Awolowo University, Ile-Ife, Nigeria

${ }^{2}$ Department of Agricultural and Environmental Engineering, Faculty of Technology, Obafemi Awolowo University, Ile-Ife, Nigeria ${ }^{3}$ Department of Soil Science and Land Resources Management, Faculty of Agriculture, Obafemi Awolowo University, Ile-Ife, Nigeria

Email: ^tope.olatoberu@gmail.com

How to cite this paper: Ojo, O.F., Ogunwande, G.A., Adesanwo, O.O. and Olatoberu, F.T. (2021) Effect of Effluent from Biodigestion of Pre-Treated Rice Bran and Animal Manure on the Dry Matter Yield and Nutrient Uptake of Amaranthus viridis. Food and Nutrition Sciences, 12, 1255-1268. https://doi.org/10.4236/fns.2021.1212092

Received: September 27, 2021

Accepted: December 20, 2021

Published: December 23, 2021

Copyright $\odot 2021$ by author(s) and Scientific Research Publishing Inc. This work is licensed under the Creative Commons Attribution International License (CC BY 4.0).

http://creativecommons.org/licenses/by/4.0/

(c) (i) Open Access

\begin{abstract}
The effect of effluents from biodigestion of pre-treated rice bran in combination with two types of animal manure on dry matter yield of Amarathus viridis was investigated using two pre-treatment methods: Soaking in ordinary distilled water and boiled in distilled water at $100^{\circ} \mathrm{C}$. The pre-treated rice bran and animal manure were mixed ( $\mathrm{w} / \mathrm{w}$ basis) to give carbon to nitrogen ratio of 35:1 and 37:1 prior to loading into the digester to make eight different treatment combinations as follow: 1) Cow dung with no rice bran (NRB + $\mathrm{CD})$; 2) Raw rice bran + cow dung $(\mathrm{RRB}+\mathrm{CD})$; 3) Soaked rice bran in ordinary distilled water + cow dung $(S R B+C D) ; 4)$ Boiled rice bran + cow dung $(\mathrm{BRB}+\mathrm{CD}) ; 5)$ Poultry manure with no rice bran $(\mathrm{NRB}+\mathrm{PM}) ; 6)$ Raw rice bran + poultry manure $(\mathrm{RRB}+\mathrm{PM})$; 7) Soaked rice bran + poultry manure $(\mathrm{SRB}+\mathrm{PM}) ; 8)$ Boiled rice bran + poultry manure $(\mathrm{BRB}+\mathrm{PM})$. Samples of different treatment combinations were collected before digestion, both the samples and resultant effluents were subjected to elemental analysis using AAS. The effluents from the biodigestion of these combinations were applied at two rates $\left(80\right.$ and $\left.150 \mathrm{~kg} \mathrm{~N} \mathrm{ha}^{-1}\right)$ to $3 \mathrm{~kg}$ air-dried and sieved soil samples $(0$ - 20) $\mathrm{cm}$ in the greenhouse, control $\left(0 \mathrm{~kg} \mathrm{~N} \mathrm{ha}^{-1}\right)$ and reference pot with NPK fertilizer at the $80 \mathrm{~kg} \mathrm{~N} \mathrm{ha}^{-1}$ were arranged in a completely randomized design replicated three times. Amaranthus plants were introduced into each treated pot, left for four weeks before harvest, dry matter yields were recorded. Results of chemical analysis of raw materials and effluents obtained after biodigestion revealed the presence of all plant nutrients in both the raw materials and resultant effluents though the former had higher values in some
\end{abstract}


nutrients than the effluent, for examples treatment combination of $\mathrm{CD}$, the values for organic carbon (42.85\%), Ca (3.41\%) and $\mathrm{Mg}(0.61 \%)$ were higher than in the resultant effluent for $\mathrm{CD}$, a similar trend was observed with other treatment combinations. Drastic reduction in heavy metal concentration was observed after digestion, $\mathrm{Pb}$ content in the raw materials for poultry manure reduced by $94.7 \%$ in the resultant effluent from BRB: PM thus making the effluent a better soil amendment. Raw chicken manure was richer in the nutrients needed for optimal crop growth however, raw cow dung had the highest. The amendment of effluent from boiled rice bran with poultry manure at $150 \mathrm{~kg} \mathrm{~N} \mathrm{ha}^{-1}$ significantly increased the dry matter yield of Amaranthus viridis over control pots, NPK pots and all other amendments thus making it a good alternative to NPK fertilizer.

\section{Keywords}

Biogas, Rice Bran, Animal Manure, Effluents, Yield, Nutrient Uptake

\section{Introduction}

Conventional farming has played an important role in improving production of food to meet human demands through intensive application of inorganic fertilizers [1]. High cost and scarcity of inorganic fertilizers in developing countries led to renewed interest in the use of unorthodox organic materials as nutrient sources for crop production especially Amaranthus viridis. Application of NPK and urea fertilizers is a normal practice in amaranthus production, however, previous reports revealed the negative impacts of continuous application of these mineral fertilizers both on soil properties and the environment [2]. The use of easily available and cheap agrowastes by vegetable farmers in peri-urban areas ensures the sustainability of vegetable production, more balanced crop nutrition and environmental sanitation. These agro wastes include animal wastes such as poultry manure and cow dung, and other plant residues [3]. However, huge quantities are needed to meet up the nutrient needs of many crops thus reducing its wide application. Therefore, there is a need for a low-cost technology for better utilization. Rice bran (RB) is the most abundant agricultural residue in rice producing countries around the world and one of the major by-products of the rice milling process. It constitutes about $20 \%$ of the paddy by weight [4] and is very rich in plant nutrients [5] [6]. Rice bran when ploughed into the soil takes a long time to decompose because of its high C:N ratio [7]. Rice farmers in Nigeria usually result to open burning to manage the huge quantities, this method is accompanied by a lot of environmental hazards.

Recently, research attention in tropical countries has shifted to the utilization of effluents from biodigestion of organic materials to improve soil fertility and yield of crops. Previous reports showed evidence of increased crop production by using effluent from biogidestion of organic materials [8]. [9] recorded in- 
crease in dry matter yield of radish through the application of effluent from biodigestion of organic materials. However, there is limited information on the use of effluents from the rice bran and its effects as soil amendments to improve yield and nutrient uptake of crops. Therefore, this study was conducted to investigate the effect of effluents from the biodigestion of pre-treated rice bran and animal manure on the Nutrient Uptake and Yield of Amaranthus viridis.

\section{Materials and Methods}

\subsection{Materials}

Rice bran used for this study was collected from Ekiti State Rice Mill Company in Ado Ekiti, Nigeria. Fresh poultry manure and cow dung were collected at the Teaching and Research Farm of the Obafemi Awolowo University, Ile-Ife, Nigeria.

\subsection{Collection of Soil Samples and Analysis}

Soils samples used for the experiment were randomly collected at $0-20 \mathrm{~cm}$ soil depth from an exhaustively cropped land which had been farmed continuously for over four years at the Teaching and Research Farm of the Obafemi Awolowo University Ile-Ife located on latitudes $7^{\circ} 31^{\prime} \mathrm{N}$ and $7^{\circ} 33^{\prime} \mathrm{N}$ and longitudes $4^{\circ} 33^{\prime} \mathrm{E}$ and $4^{\circ} 34^{\prime} \mathrm{E}$, in the rain forest zone of southwest Nigeria. The experimental soil was classified as Iwo series (ultisol) [10]. The soil samples were air dried and sieved. The fraction that passed through a $5 \mathrm{~mm}$ was used for greenhouse studies while the fraction that passed through a $2 \mathrm{~mm}$ sieve was subjected to both physical and chemical analysis in the laboratory of the Department of Soil Science and Land Resources Management. The particle size distribution was determined using the modified method of [11] described by [12] Soil $\mathrm{pH}$ was determined using a glass electrode $\mathrm{pH}$ meter in $0.01 \mathrm{M} \mathrm{CaCl}_{2}$ solution, [13] and modified by [14]. Total $\mathrm{N}$ was determined using the method described by [15]. Soil organic matter was determined using the method described by [16] as modified by [17]. Available P was extracted by Bray-1 method described by [18] as modified by [19], Visible Spectrophotometer Model 721, Axiom Mediral LMD. U.K.). Exchangeable cations were extracted using $1 \mathrm{~N}-\mathrm{NH}_{4} \mathrm{OAc}$ [20] as modified by [21]. Concentrations of $\mathrm{K}$ and $\mathrm{Na}$ in the solution were determined with the flame photometer (PG-FP902 microprocessor model) while $\mathrm{Ca}, \mathrm{Mg}$ concentrations were determined using atomic absorption spectrophotometer PG-AA500FG model. The exchangeable acidity was determined by $1 \mathrm{~N} \mathrm{KCl}$ extraction solution [22]. The soil CEC was determined by the addition of exchangeable and exchangeable acidity [20] [23] modified by [24]. Micro nutrients contents (Fe, Zn, Mn $\mathrm{Cu})$, and Heavy metals $(\mathrm{Pb}, \mathrm{Cd})$ were also determined [25].

\subsection{Pre-Treatment of the Materials}

Two pre-treatment methods were used: rice bran boiled at $100^{\circ} \mathrm{C}$ for 30 minutes in (BRB), rice bran soaked for 72 hours in ordinary distilled water at ambient temperature of $29.6^{\circ} \mathrm{C} \pm 3.4^{\circ} \mathrm{C}$ (SRB. Pre-treated rice bran and animal manure 
were mixed (w/w basis) to give carbon to nitrogen ratio of 35:1 and 37:1 prior to loading into the digesters. Eight different treatment combinations were subjected to anaerobic digestion for 16 weeks at the Department of Agricultural and Environmental Engineering 1) Cow dung with no rice bran (CD); 2) Raw rice bran + cow dung (RRB:CD); 3) Soaked rice bran + cow dung (SRB:CD); 4) Boiled rice bran + cow dung (BRB:CD); 5) Poultry manure with no rice bran (PM); 6) Raw rice bran + poultry manure (RRB:PM); 7) Soaked rice bran + poultry manure (SRB:PM); 8) Boiled rice bran + poultry manure (BRB:PM). The mixture was digested for 16 weeks and the digestion was carried out at the Department of Agricultural and Environmental Engineering). The control treatments had zero level of rice bran. After the mixing, the digesters were loaded and the digesters were then hermetically sealed. The digesters were agitated manually twice daily to ensure intimate contact between micro-organisms and the substrate as well as uniform heat distribution.

\subsection{Analysis of Effluent Nutrients}

Effluent samples (digested slurry) were collected for each treatment and analysed for the following parameters: total nitrogen (TN), available phosphorus $(\mathrm{P})$, potassium $(\mathrm{K})$, total organic carbon (TOC), iron (Fe), calcium $(\mathrm{Ca})$, magnesium $(\mathrm{Mg})$, zinc $(\mathrm{Zn})$, manganese $(\mathrm{Mn})$ and $\mathrm{pH}$.

\subsection{Greenhouse Experiment}

The effect of effluents generated from the biogas production on the growth of Amaranthus viridis was tested in the greenhouse of the Faculty of Agriculture, Obafemi Awolowo University, Ile-Ife. Three kilogrammes of air-dried and sieved surface soil were filled into each $7 \mathrm{~cm} \times 19.2 \mathrm{~cm} \times 13.8 \mathrm{~cm}$ (height $\mathrm{x}$ top diameter $\times$ base diameter) pot. The pots had perforations underneath to prevent water logging and ensure soil aeration. The pots were arranged in complete randomized design, control pots and reference pots $\left(80 \mathrm{Kg} \mathrm{N}^{-1} \mathrm{NPK}\right.$ fertilizer) were included to make a total of 10 treatments. The effluents were incorporated into the soil at application rates of 80 and $150 \mathrm{~kg} \mathrm{~N} \mathrm{ha}^{-1}$ two weeks prior to sowing of Amaranthus viridis. All were replicated thrice to give a total of 54 pots labeled and arranged in a completely randomized design. The pots were moistened to and maintained at $70 \%$ of the soil's field moisture capacity and the applied treatments were allowed to undergo incubation for a period of two weeks. Seeds of Amaranthus viridis were sown into each pot and thinned to two stands, one week after sowing (WAS).

\subsection{Plant Analysis}

\subsubsection{Determination of Plant Dry Matter and Moisture Content}

The edible portions of the Amaranthus viridis (Leaves + Succulent stem) were harvested after four weeks, kept in polythene bag and immediately transported to Soil Testing Laboratory of the Department of Soil Science and Land Resources Management. The harvested plant samples were oven dried at $60^{\circ} \mathrm{C}$ until a con- 
stant weight was obtained. The percent dry matter was determined according to [26]

$$
\% \text { Dry matter }=\frac{\text { Weight of Dry Sample }}{\text { Weight of Fresh Sample }} \times \frac{100}{1} .
$$

The percent plant moisture content of the plant tissue was determined using the expression:

$$
\% \text { water content }=\frac{(\text { Weight of Fresh Sample })-(\text { Weight of Dry Sample })}{\text { Weight of Fresh Sample }} \times \frac{100}{1} .
$$

\subsubsection{Determination of Nutrient Uptake}

The nutrients in the plant samples were extracted using wet ash digestion method. Nitrogen content was determined using Kjeldahl method as described by [15]. Other nutrients (P, K, Ca, Fe, Mg, Zn, Mn, Pb, Cr, Cd, Ar, Ni and $\mathrm{Hg}$ ) were determined using method as described by AOAC [27]. The nutrient uptake was determined according to [26].

$$
\begin{aligned}
& \text { Dry matter weight }(\mathrm{gm}) \\
& =\text { wet weight }(\mathrm{gm})-\left[\text { wet weight }(\mathrm{gm}) \times \frac{\text { moisture }(\%)}{100 \%}\right] \\
& \text { Dry matter yield }\left(\frac{\mathrm{kg}}{\text { hectare }}\right)=\frac{\text { dry matter weight }(\mathrm{kg})}{\text { area of Harvested land }} \\
& \text { Nutrient removal }\left(\frac{\mathrm{kg}}{\text { hectare }}\right) \\
& =\frac{\text { dry matter yield }(\mathrm{kg} / \text { hectare }) \times \text { concentration }(\%)}{100 \%}
\end{aligned}
$$

\subsection{Statistical Analysis}

The data obtained from anaerobic digestion was subjected to two-way analysis of variance (ANOVA) to determine variation in properties. Where significance was indicated, the means were separated using Duncan's New Multiple Range Test (DMRT) at 5\% significance level. However, greenhouse experiment data was subjected to one-way analysis of variance (ANOVA) and means were separated using Duncan's New Multiple Range Test at 5\% significance level. The statistical analysis was performed using the GLM procedure of Statistical Analysis System [28] software.

\section{Result and Discussion}

\subsection{Physicochemical Properties of Soil}

The physical and chemical properties of the soil used in the study were presented in Table 1. The soil was loamy sand in texture with $\mathrm{pH}$ of 6.5 indicating a slightly acidic condition. Total $\mathrm{N}\left(1.0 \mathrm{~g} \cdot \mathrm{kg}^{-1}\right)$, organic carbon $\left(17.3 \mathrm{~g} \cdot \mathrm{kg}^{-1}\right)$, available $\mathrm{P}\left(7.46 \mathrm{mg} \cdot \mathrm{kg}^{-1}\right)$ and exchangeable $\mathrm{Mg}\left(0.18 \mathrm{cmol} \cdot \mathrm{kg}^{-1}\right)$ were below the 
Table 1. Pre-planting physical and chemical characteristics of soils.

\begin{tabular}{|c|c|}
\hline Parameters & Mean values \\
\hline pH (1:1 soil to water) & 6.5 \\
\hline Total N $\left(\mathrm{g} \cdot \mathrm{kg}^{-1}\right)$ & 1.0 \\
\hline Total organic carbon $\left(\mathrm{g} \cdot \mathrm{kg}^{-1}\right)$ & 17.3 \\
\hline Available P (mg.kg ${ }^{-1}$ ) & 7.46 \\
\hline \multicolumn{2}{|l|}{ Exchangeable cations $\left(\mathrm{cmol} \cdot \mathrm{kg}^{-1}\right)$} \\
\hline $\mathrm{Ca}^{2+}$ & 0.34 \\
\hline $\mathrm{Mg}^{2+}$ & 0.18 \\
\hline $\mathrm{K}^{+}$ & 0.50 \\
\hline $\mathrm{Na}^{+}$ & 0.30 \\
\hline $\mathrm{CEC}\left(\mathrm{cmol} \cdot \mathrm{kg}^{-1}\right)$ & 1.40 \\
\hline Exchangeable Acidity $\mathrm{H}^{+}\left(\mathrm{cmol} \cdot \mathrm{kg}^{-1}\right)$ & 0.09 \\
\hline \multicolumn{2}{|l|}{ Micronutrients $\left(\mathrm{mg} \cdot \mathrm{kg}^{-1}\right.$ ) } \\
\hline $\mathrm{Fe}$ & 0.16 \\
\hline $\mathrm{Zn}$ & 0.10 \\
\hline Mn & 0.08 \\
\hline $\mathrm{Cu}$ & 0.06 \\
\hline \multicolumn{2}{|l|}{ Heavy metals $\left(\mathrm{mg} \cdot \mathrm{kg}^{-1}\right)$} \\
\hline $\mathrm{Pb}$ & 0.01 \\
\hline $\mathrm{Cd}$ & 0.01 \\
\hline \multicolumn{2}{|l|}{ Particle size distribution $\left(\mathrm{g} \cdot \mathrm{kg}^{-1}\right)$} \\
\hline Sand & 105.5 \\
\hline Silt & 838.0 \\
\hline Clay & 58.0 \\
\hline Textural class & Loamy sand \\
\hline
\end{tabular}

critical values for soils of Southwestern Nigeria according to [29]. Similarly, micronutrient contents were below the critical values for optimum crop production [30] thus indicating the low fertility status of the soil.

\subsection{Selected Chemical Properties of the Feedstock and Effluent}

The nutrients and heavy metal contents in feedstock and effluents were presented in Table 2 and Table 3. The results revealed the high nutrient content of raw poultry manure compared with other feedstocks, for example, highest values in $\mathrm{N}(4.48 \%)$ and $\mathrm{P}(1.93 \%)$ were recorded for raw poultry manure values in while raw cow dung had the highest organic carbon, $\mathrm{Ca}$ and $\mathrm{Mg}$ (42.85\%, 3.41\% and $0.61 \%$, respectively). Rice bran had the highest $\mathrm{K}$ value (2.37\%). Raw poultry manure gave highest Fe (528 mg. $\left.\mathrm{kg}^{-1}\right), \mathrm{Zn}\left(475 \mathrm{mg} \cdot \mathrm{kg}^{-1}\right), \mathrm{Mn}\left(644 \% \mathrm{mg} \cdot \mathrm{kg}^{-1}\right), \mathrm{Pb}$ 
Table 2. Nutrient content in feedstock and effluents.

\begin{tabular}{ccccccc}
\hline & \multicolumn{7}{c}{ Elements } \\
\cline { 2 - 7 } Feedstock & $\mathrm{N}$ & $\mathrm{P}$ & $\mathrm{K}$ & $\mathrm{TOC}$ & $\mathrm{Ca}$ & $\mathrm{Mg}$ \\
\cline { 2 - 7 } & \multicolumn{7}{c}{$\%$} & & \\
\hline Cow Dung & 1.26 & 1.63 & 0.44 & 42.85 & 3.41 & 0.61 \\
Poultry manure & 4.48 & 1.93 & 1.43 & 40.15 & 3.26 & 0.56 \\
Rice bran & 1.47 & 1.37 & 2.37 & 15.80 & 0.07 & 0.48 \\
Effluents & & & & & & \\
NRB:CD & 2.51 & 1.43 & 0.33 & 26.94 & 3.22 & 0.48 \\
RRB:CD & 2.58 & 1.40 & 0.59 & 24.91 & 3.06 & 0.54 \\
SRB:CD & 3.23 & 1.39 & 0.37 & 33.48 & 3.42 & 0.52 \\
BRB:CD & 2.85 & 1.40 & 0.43 & 28.55 & 3.26 & 0.49 \\
NRB:PM & 3.28 & 1.83 & 1.26 & 33.63 & 2.92 & 0.47 \\
RRB:PM & 3.43 & 1.78 & 1.25 & 36.03 & 2.86 & 0.43 \\
SRB:PM & 3.48 & 1.83 & 1.32 & 35.99 & 3.45 & 0.41 \\
BRB:PM & 3.63 & 1.78 & 1.32 & 37.78 & 3.78 & 0.51 \\
\hline
\end{tabular}

Where NRB:CD = no rice bran + cow dung; RRB:CD = raw rice bran + cow dung; SRB:CD = soaked rice bran + cow dung; $\mathrm{BRB}: \mathrm{CD}=$ boiled rice bran + cow dung; $\mathrm{NRB}: \mathrm{PM}=$ no rice bran + poultry manure; $\mathrm{RRB}: \mathrm{PM}=$ raw rice bran + poultry manure; $\mathrm{SRB}: \mathrm{PM}=$ soaked rice bran + poultry manure; $\mathrm{BRB}: \mathrm{PM}=$ boiled rice bran + poultry manure.

Table 3. Micro nutrients and heavy metals concentration in feedstock and effluent.

\begin{tabular}{|c|c|c|c|c|c|c|c|c|c|}
\hline \multirow{3}{*}{ Feedstock } & \multicolumn{9}{|c|}{ Elements } \\
\hline & $\mathrm{Fe}$ & $\mathrm{Zn}$ & $\mathrm{Mn}$ & $\mathrm{Pb}$ & $\mathrm{Cd}$ & $\mathrm{Cr}$ & $\mathrm{Ar}$ & $\mathrm{Ni}$ & $\mathrm{Hg}$ \\
\hline & \multicolumn{9}{|c|}{$\mathrm{mg} \cdot \mathrm{kg}^{-1}$} \\
\hline Cow Dung & 126.25 & 183.25 & 391.00 & 2.84 & 0.21 & 3.60 & 2.93 & 2.34 & 2.84 \\
\hline Poultry manure & 528.70 & 475.10 & 644.50 & 24.45 & 3.06 & 30.11 & 12.80 & 1.95 & 0.81 \\
\hline Rice bran & 1.11 & 0.94 & 3.47 & 0.18 & 0.26 & 0.01 & 0.01 & 0.83 & 0.15 \\
\hline \multicolumn{10}{|l|}{ Effluents } \\
\hline NRB:CD & 12.51 & 14.54 & 13.06 & 1.11 & 0.11 & 0.06 & 0.03 & 0.02 & 0.01 \\
\hline RRB:CD & 12.08 & 14.58 & 12.87 & 1.12 & 0.11 & 0.03 & 0.02 & 0.01 & 0.01 \\
\hline SRB:CD & 13.49 & 14.77 & 13.77 & 1.19 & 0.11 & 0.02 & 0.01 & 0.01 & 0.01 \\
\hline BRB:CD & 12.51 & 14.08 & 13.15 & 1.11 & 0.09 & 0.03 & 0.02 & 0.01 & 0.01 \\
\hline NRB:PM & 14.67 & 15.49 & 13.62 & 1.26 & 0.16 & 0.03 & 0.02 & 0.01 & 0.01 \\
\hline RRB:PM & 14.72 & 15.34 & 13.37 & 1.22 & 0.13 & 0.03 & 0.01 & 0.01 & 0.01 \\
\hline SRB:PM & 15.41 & 15.35 & 13.15 & 1.31 & 0.10 & 0.02 & 0.01 & 0.01 & 0.01 \\
\hline BRB:PM & 15.76 & 15.60 & 13.72 & 1.28 & 0.13 & 0.01 & 0.01 & 0.01 & 0.01 \\
\hline
\end{tabular}

Where NRB:CD = no rice bran + cow dung; $\mathrm{RRB}: \mathrm{CD}$ = raw rice bran + cow dung; $\mathrm{SRB}: \mathrm{CD}$ = soaked rice bran + cow dung; $\mathrm{BRB}: \mathrm{CD}=$ boiled rice bran + cow dung; $\mathrm{NRB}: \mathrm{PM}=$ no rice bran + poultry manure; $R R B: P M=$ raw rice bran + poultry manure; $S R B: P M=$ soaked rice bran + poultry manure; $\mathrm{BRB}: \mathrm{PM}=$ boiled rice bran + poultry manure. 
(24.45 mg. $\left.\mathrm{kg}^{-1}\right), \mathrm{Cd}\left(3.06 \mathrm{mg} \cdot \mathrm{kg}^{-1}\right), \mathrm{Cr}\left(30.11 \mathrm{mg} \cdot \mathrm{kg}^{-1}\right)$ and $\mathrm{Ar}\left(12.80 \mathrm{mg} \cdot \mathrm{kg}^{-1}\right)$. However, raw cow dung gave highest $\mathrm{Ni}$ and $\mathrm{Hg}$.

The result of chemical composition of effluent of different treatment combinations after bio digestion showed higher nutrient content compared with raw feedstocks, for example, $\mathrm{N}$ content in the effluent $\mathrm{CD}$ without rice bran (2.51\%) was higher than raw $\mathrm{CD}(1.26 \%)$, similar observation was also reported in previous studies [31] [32] [33]. Among the different feedstocks subjected to biogestion, effluent from poultry manure effluent (PM, RRB: PM, SRB: PM and BRB: PM) contained higher amount of TOC, N, P, K, Fe and Zn compared to effluent of rice bran and cowdung. Drastic reduction in the micronutrients and heavy metal contents of the effluents from biodigestion compared to raw feedstocks was observed, thus showing the potential of these effluents as an environmental-friendly alternative fertilizer for sustainable soil management. For example, about 98\% decrease in $\mathrm{Pb}$ content was recorded for all PM treatments compared to the raw sample. In addition, likehoodly of micronutrients toxicity will be less pronounced with the effluents compared to application of raw samples. These results are in close conformity with previous work by [34]. Result of chemical composition of the effluent from bio digestion of combined rice bran and animal manure showed the potential of these effluents as a viable alternative to mineral fertilizer. Almost all the plant nutrients were present in an adequate amount.

\subsection{Effects of Effluent from Bio-Digestion of Rice Bran with Animal Manure Treatment on Dry Matter Yield, Nitrogen, Phosphorus and Potassium Uptake of Amaranthus viridis Plants}

The results showing the effects of effluents from biodigestion of rice bran and animal manure on dry matter yield, nitrogen, phosphorus and potassium uptake of Amaranthus viridis were presented in Table 4. Application of effluents from different treatment combinations significantly increased dry matter yield of Amaranthus viridis over the control pot, highest dry matter yield was recorded from pot treated with effluent from biodigestion of BRB:PM at the rate of $150 \mathrm{~kg}$ $\mathrm{N} \mathrm{ha}^{-1}$ and significantly higher than NPK treated pot, this is an indication of the potential of effluents from biodigestion of organic materials as viable alternative to mineral fertilizer. This result was in close conformity with earlier research findings [9] [35] [36] [37]. In addition, no significant difference in the dry matter yield was observed among all the pots treated with effluents at $80 \mathrm{~kg} \mathrm{~N} \mathrm{ha}^{-1}$ and NPK treated pot.

Pots treated with effluents and NPK fertilizer significantly $(\mathrm{p}<0.05)$ had higher N. P and K uptake over the control pot. However, highest values in $\mathrm{N}$ and $\mathrm{K}$ uptake were recorded in pots treated with NPK fertilizer while plants harvested from pot treated with $\mathrm{BRB}$ : $\mathrm{PM}$ at rate of $150 \mathrm{~kg} \mathrm{~N} \mathrm{ha}^{-1}$ had the highest $\mathrm{P}$ uptake. The increased $\mathrm{N}$ and $\mathrm{K}$ uptake in NPK treated pot over effluents treated pots could be as a result its high solubility. The result corroborated the work of [38] who reported significant increase in the nutrients content of cucumber leaf. 
Table 4. Dry matter yield, nitrogen, phosphorus and potassium uptake of Amaranthus viridis plants.

\begin{tabular}{|c|c|c|c|c|c|}
\hline \multirow{2}{*}{ Treatments } & Rates & DMY & $\mathrm{N}$ & $\mathrm{P}$ & $\mathrm{K}$ \\
\hline & $\left(\mathrm{kg} \mathrm{N} \mathrm{ha}^{-1}\right)$ & g & \multicolumn{3}{|c|}{$\mathrm{mg} \cdot \mathrm{kg}^{-1}$} \\
\hline Control & 0 & $15.01^{c}$ & $8.00^{1}$ & $13.01^{1}$ & $15.76^{\mathrm{m}}$ \\
\hline NPK & 80 & $15.88^{\mathrm{cd}}$ & $78.61^{\mathrm{a}}$ & $78.30^{\mathrm{e}}$ & $248.07^{\mathrm{a}}$ \\
\hline \multirow{2}{*}{ NRB:CD } & 80 & $14.21^{\mathrm{f}}$ & $60.36^{\mathrm{hi}}$ & $51.91^{\mathrm{j}}$ & $49.36^{j}$ \\
\hline & 150 & $15.20^{c}$ & $70.48^{\mathrm{cd}}$ & $68.12^{\mathrm{g}}$ & $65.85^{\mathrm{i}}$ \\
\hline \multirow{2}{*}{ SRB:CD } & 80 & $14.47^{\mathrm{f}}$ & $57.22^{\mathrm{jk}}$ & $72.66^{\mathrm{f}}$ & $20.54^{1}$ \\
\hline & 150 & $15.61^{\mathrm{d}}$ & $72.52^{b c}$ & $88.74^{c}$ & $49.59^{j}$ \\
\hline \multirow{2}{*}{ RRB:CD } & 80 & $16.42^{\mathrm{ab}}$ & $68.96^{\mathrm{de}}$ & $82.14^{\mathrm{d}}$ & $47.95^{j}$ \\
\hline & 150 & $15.81^{\mathrm{cd}}$ & $72.66^{\mathrm{bc}}$ & $97.62^{b}$ & $67.06^{\mathrm{i}}$ \\
\hline \multirow{2}{*}{ BRB:CD } & 80 & $14.53^{\mathrm{f}}$ & $65.24^{\mathrm{fg}}$ & $57.89^{\mathrm{i}}$ & $48.00^{j}$ \\
\hline & 150 & $16.00^{c}$ & $71.20^{\mathrm{cd}}$ & $68.54^{\mathrm{g}}$ & $41.05^{\mathrm{k}}$ \\
\hline \multirow{2}{*}{ NRB:PM } & 80 & $14.49^{\mathrm{f}}$ & $54.33^{\mathrm{k}}$ & $47.29^{\mathrm{k}}$ & $164.62^{\mathrm{h}}$ \\
\hline & 150 & $15.09^{c}$ & $60.34^{\mathrm{hi}}$ & $59.56^{\mathrm{i}}$ & $183.66^{\mathrm{f}}$ \\
\hline \multirow{2}{*}{ SRB:PM } & 80 & $15.80^{\mathrm{cd}}$ & $62.56^{\mathrm{gh}}$ & $69.37^{\mathrm{g}}$ & $208.48^{\mathrm{d}}$ \\
\hline & 150 & $16.07^{\mathrm{bc}}$ & $67.16^{\mathrm{ef}}$ & $79.47^{\mathrm{de}}$ & $204.81^{\mathrm{e}}$ \\
\hline \multirow{2}{*}{ RRB:PM } & 80 & $15.09^{c}$ & $57.60^{\mathrm{ij}}$ & $63.90^{\mathrm{h}}$ & $180.88^{\mathrm{g}}$ \\
\hline & 150 & $16.06^{\mathrm{bc}}$ & $69.78^{\mathrm{de}}$ & $81.13^{\mathrm{d}}$ & $211.34^{\mathrm{c}}$ \\
\hline \multirow{2}{*}{ BRB:PM } & 80 & $14.52^{\mathrm{f}}$ & $62.48^{\text {hg }}$ & $76.84^{\mathrm{e}}$ & $207.64^{\mathrm{d}}$ \\
\hline & 150 & $16.65^{\mathrm{a}}$ & $75.22^{\mathrm{b}}$ & $102.97^{a}$ & $229.58^{\mathrm{b}}$ \\
\hline
\end{tabular}

Means having the same letter(s) in the columns are not significantly different at $5 \%$ significant level. Where NRB:CD = no rice bran + cow dung; RRB:CD = raw rice bran + cow dung; SRB:CD = soaked rice bran + cow dung; $\mathrm{BRB}: \mathrm{CD}=$ boiled rice bran + cow dung; $\mathrm{NRB}: \mathrm{PM}=$ no rice bran + poultry manure; $\mathrm{RRB}: \mathrm{PM}=$ raw rice bran + poultry manure; $\mathrm{SRB}: \mathrm{PM}=$ soaked rice bran + poultry manure; $\mathrm{BRB}: \mathrm{PM}=$ boiled rice bran + poultry manure.

\subsection{Effects of Effluent from Bio-Digestion of Rice Bran with Animal Manure Treatment on Calcium and Magnesium Uptake of Amaranthus viridis Plants}

Positive significant $(\mathrm{p}<0.05)$ effects of the effluents and NPK treatments over control pot were recorded for $\mathrm{Ca}$ and $\mathrm{Mg}$ uptake in Amaranthus viridis as presented in Figure 1.

\subsection{Effects of Effluent from Bio-Digestion of Rice Bran with Animal Manure Treatment on Heavy Metal Uptake of Amaranthus viridis Plants}

The result showing the uptake of heavy metals in Amaranthus viridis as 


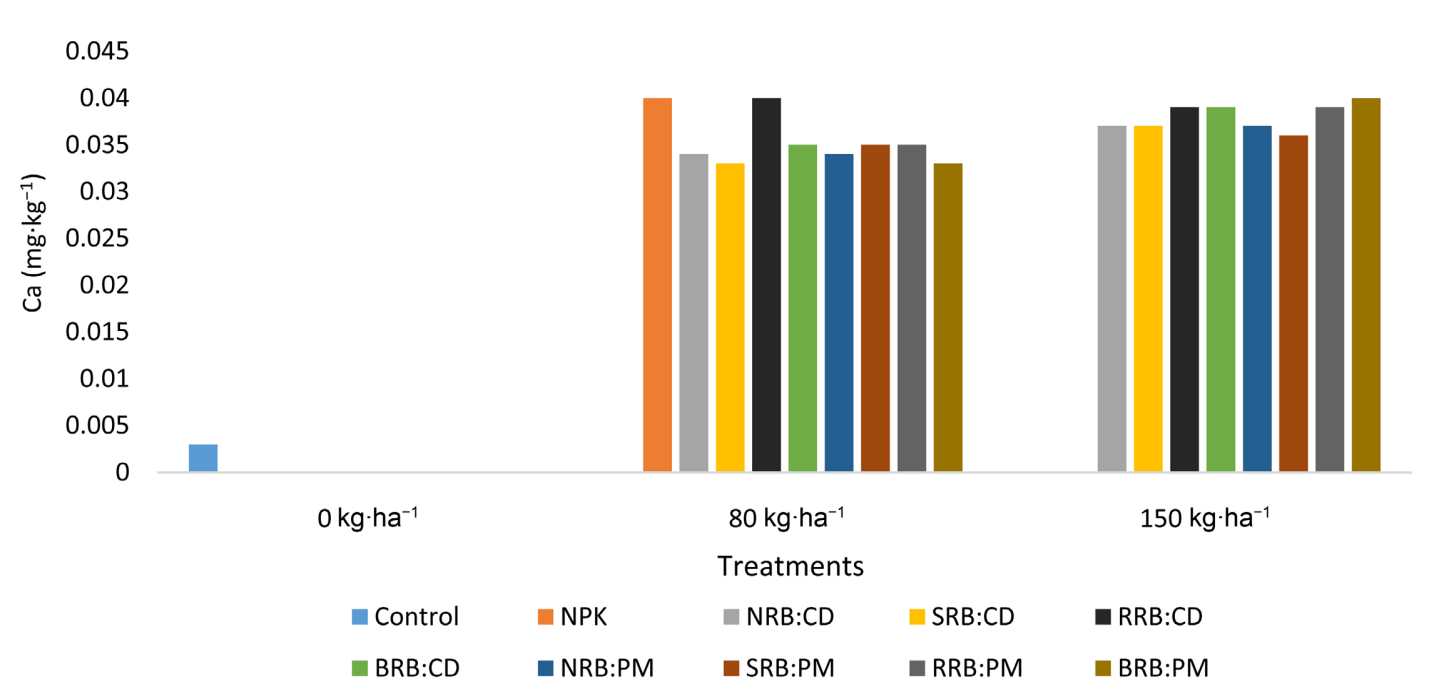

(a)

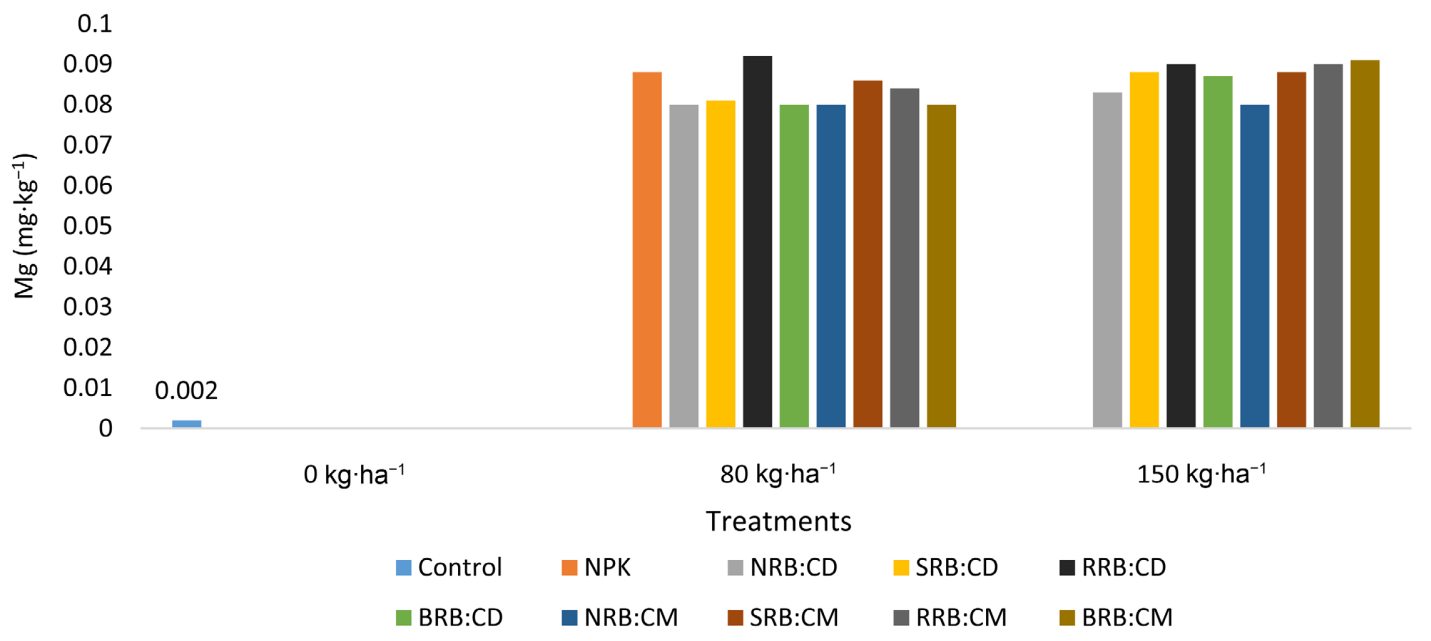

(b)

Figure 1. (a) Calcium uptake of Amaranthus viridis plants; (b) Magnesiun uptake of Amaranthus viridis plants.

influenced by the application of effluents from different treatment combinations was presented in Table 5. Extremely low values in all the heavy metals studied further support the potential of using effluents from biodigestion of rice bran and animal manure as viable fertilizer compared with mineral fertilizer.

\section{Conclusion}

The study revealed the high plant nutrient status of effluents from biodigestion of rice bran with animal manure, extremely low amount of micronutrients and heavy metal too showed the potentials of using these effluents as a viable alternative to mineral fertilizers. The positive impact of the effluents on nutrient uptake and yield of Amaranthus viridis observed further confirmed its suitability as a good soil amendment. This study confirmed the effectiveness of effluent from bio digestion of rice bran with animal manure as a low cost, environmentally friendly 
Table 5. Heavy metal uptake of Amaranthus viridis plants.

\begin{tabular}{|c|c|c|c|c|c|c|c|}
\hline \multirow{2}{*}{ Treatments } & Rates & $\mathrm{Pb}$ & $\mathrm{Cd}$ & $\mathrm{Cr}$ & As & $\mathrm{Ni}$ & $\mathrm{Hg}$ \\
\hline & $\left(\mathrm{kg} \mathrm{N} \mathrm{ha}^{-1}\right)$ & \multicolumn{6}{|c|}{$\mathrm{mg} \cdot \mathrm{kg}^{-1}$} \\
\hline Control & 0 & 0.0002 & $0.0002^{1}$ & $0.0001^{\mathrm{c}}$ & $0^{\mathrm{d}}$ & $\mathrm{Nd}$ & $\mathrm{Nd}$ \\
\hline NPK & 80 & $0.0002^{\mathrm{i}}$ & $0.0002^{1}$ & $0^{\mathrm{d}}$ & $0^{\mathrm{d}}$ & $\mathrm{Nd}$ & $\mathrm{Nd}$ \\
\hline \multirow{2}{*}{ NRB:CD } & 80 & $0.0004^{\mathrm{g}}$ & $0.0006^{\mathrm{h}}$ & $0^{\mathrm{d}}$ & $0^{\mathrm{d}}$ & $\mathrm{Nd}$ & $\mathrm{Nd}$ \\
\hline & 150 & $0.0007^{c}$ & $0.0008^{f}$ & $0^{\mathrm{d}}$ & $0^{\mathrm{d}}$ & $\mathrm{Nd}$ & $\mathrm{Nd}$ \\
\hline \multirow{2}{*}{ SRB:CD } & 80 & $0.0004^{\mathrm{g}}$ & $0.0006^{\mathrm{h}}$ & $0.0001^{c}$ & $0^{\mathrm{d}}$ & $\mathrm{Nd}$ & $\mathrm{Nd}$ \\
\hline & 150 & $0.0009^{c}$ & $0.0007^{\mathrm{g}}$ & $0.0002^{\mathrm{b}}$ & $0^{\mathrm{d}}$ & $\mathrm{Nd}$ & $\mathrm{Nd}$ \\
\hline \multirow{2}{*}{ RRB: CD } & 80 & $0.0012^{\mathrm{b}}$ & $0.0013^{c}$ & $0.0002^{b}$ & $0.00001^{c}$ & $\mathrm{Nd}$ & $\mathrm{Nd}$ \\
\hline & 150 & $0.0015^{a}$ & $0.0019^{\mathrm{a}}$ & $0.0003^{\mathrm{a}}$ & $0.00004^{\mathrm{b}}$ & $\mathrm{Nd}$ & $\mathrm{Nd}$ \\
\hline \multirow{2}{*}{ BRB:CD } & 80 & $0.0002^{\mathrm{i}}$ & $0.0003 \mathrm{k}$ & $0^{\mathrm{d}}$ & $0^{\mathrm{d}}$ & $\mathrm{Nd}$ & $\mathrm{Nd}$ \\
\hline & 150 & $0.0005^{\mathrm{f}}$ & $0.0006^{\mathrm{h}}$ & $0^{\mathrm{d}}$ & $0^{\mathrm{d}}$ & $\mathrm{Nd}$ & $\mathrm{Nd}$ \\
\hline \multirow{2}{*}{ NRB:PM } & 80 & $0.0003^{\mathrm{h}}$ & $0.0005^{\mathrm{i}}$ & $0^{\mathrm{d}}$ & $0^{\mathrm{d}}$ & $\mathrm{Nd}$ & $\mathrm{Nd}$ \\
\hline & 150 & $0.0003^{\mathrm{h}}$ & $0.0008^{f}$ & $0^{\mathrm{d}}$ & $0^{\mathrm{d}}$ & $\mathrm{Nd}$ & $\mathrm{Nd}$ \\
\hline \multirow{2}{*}{ SRB:PM } & 80 & $0.0003^{\mathrm{h}}$ & $0.0004^{j}$ & $0.0002^{b}$ & $0^{\mathrm{d}}$ & $\mathrm{Nd}$ & $\mathrm{Nd}$ \\
\hline & 150 & $0.0004^{\mathrm{g}}$ & $0.0004^{j}$ & $0.0002^{\mathrm{b}}$ & $0^{\mathrm{d}}$ & $\mathrm{Nd}$ & $\mathrm{Nd}$ \\
\hline \multirow{2}{*}{ RRB:PM } & 80 & $0.0008^{\mathrm{d}}$ & $0.0010^{\mathrm{d}}$ & $0.0003^{\mathrm{a}}$ & $0.00001^{c}$ & $\mathrm{Nd}$ & $\mathrm{Nd}$ \\
\hline & 150 & $0.0012^{\mathrm{b}}$ & $0.0016^{\mathrm{b}}$ & $0.0003^{\mathrm{a}}$ & $0.00006^{\mathrm{a}}$ & $\mathrm{Nd}$ & $\mathrm{Nd}$ \\
\hline \multirow{2}{*}{ BRB:CM } & 80 & $0.0005^{\mathrm{f}}$ & $0.0006^{\mathrm{h}}$ & $0.0002^{b}$ & $0.00001^{c}$ & $\mathrm{Nd}$ & $\mathrm{Nd}$ \\
\hline & 150 & $0.0009^{c}$ & $0.0009^{\mathrm{e}}$ & $0.0002^{\mathrm{b}}$ & $0.00006^{\mathrm{a}}$ & $\mathrm{Nd}$ & $\mathrm{Nd}$ \\
\hline
\end{tabular}

Means having the same letter(s) in the columns are not significantly different at $5 \%$ significant level. Where NRB:CD = no rice bran + cow dung; $\mathrm{RRB}: \mathrm{CD}=$ raw rice bran + cow dung; $\mathrm{SRB}: \mathrm{CD}=$ soaked rice bran + cow dung; $\mathrm{BRB}: \mathrm{CD}=$ boiled rice bran + cow dung, $\mathrm{NRB}: \mathrm{PM}=$ no rice bran + poultry manure; RRB:PM = raw rice bran + poultry manure; SRB:PM = soaked rice bran + poultry manure; $\mathrm{BRB}: \mathrm{PM}=$ boiled rice bran + poultry manure.

fertilizer over mineral fertilizer for the production of Amaranthus viridis. This will ensure food security at a sustainable level.

\section{Conflicts of Interest}

The authors declare no conflicts of interest regarding the publication of this paper.

\section{References}

[1] Tu, C., Louws, F.J., Creamer, N.G., Mueller, J.P., Brownie, C., Fager, K., Bell, M. and $\mathrm{Hu}, \mathrm{S}$. (2006) Responses of Soil Microbial Biomass and N Availability to Transition Strategies from Conventional to Organic Farming Systems. Agriculture, Ecosystems \& Environment, 113, 206-215. https://doi.org/10.1016/j.agee.2005.09.013 
[2] Awodun, M.A. (2021) The Nexus of Population, Food Security, Climate Change and Plant Nutrition: Organic Wastes as Alternative Fertilizer in Nigeria. Inaugural Lecture Series 129. The Federal University of Technology, Akure, 41.

[3] Ayeni, L.S., Adeleye, E.O. and Adejumo, J.O. (2012) Comparative Effect of Organic, Organomineral and Mineral Fertilizers on Soil Properties, Nutrient Uptake, Growth and Yield of Maize (Zea mays). International Research Journal of Agricultural Science and Soil Science, 2, 493-497.

[4] Vigil, S., Theisen, H. and Tehobanoglous, G. (1993) Integrated Solid Waste Management. Engineering Principle and Management Issues. McGraw-Hill Inc., Singapore, 20-34.

[5] Moyin Jesu, E.I. (2003) Incorporation of Agricultural Biomas and Their Effects on Growth and Nutrient Content of Four Successive Crops of Amaranthus. Partanika Journal of Tropical Agricultural Science, 26, 49-58.

[6] Odedina, S.A., Ojeniyi, S.O. and Awodun, M.A. (2007) Effect of Agro Industrial Wastes on Nutrients Status and Performances of Tomato. Global Journal of Environmental Research, 1, 18-21.

[7] Pillaier, P. (1998) RICE: Post Production Manual. Willey Eastern Limited, New Delhi.

[8] Tambone, F., Scaglia, B., D’Imporzano, G. and Schievano, A. (2010) Assessing Amendment and Fertilizing Properties of Digestates from Anaerobic Digestion through a Comparative Study with Digested Sludge and Compost. Chemosphere, 81, 577-583. https://doi.org/10.1016/j.chemosphere.2010.08.034

[9] Sekar, S. (2012) The Effect of Biochar and Anaerobic Digester Effluent on Soil Quality and Crop Growth in Karnataka India. M.Sc. Thesis, Department of Environmental and Natural Resources, Ohio State University, Columbus, 114 p.

[10] Smyth and Montgomery, R.F. (1962) The Soil and Land Use of Central Western Nigeria. The Government Printer, Ibadan, 265 p.

[11] Bouyoucos, G.F. (1965) Hydrometer Method Improved for Making Particle Size Analysis of Soils. Soil Science Society of America Proceedings, 26, 464-465. https://doi.org/10.2134/agronj1962.00021962005400050028x

[12] Gee, G.W. and Or, D.B. (2002) Particle Size Analysis. In: Dane, J.H. and Topp, G.C., Eds., Method of Soil Analysis Part 4, Physical Methods, Soil Science Society of America Book Series No. 5, ASA and SSSA, Madison, 255-293.

https://doi.org/10.2136/sssabookser5.4.c12

[13] Peech, M. (1965) Hydrogen-Ion Activity. In: Black, C.A., Ed., Methods of Soil Analysis. Part 2, Agronomy Monographs 9, ASA and SSSA, Madison, 914-926.

https://doi.org/10.2134/agronmonogr9.2.c9

[14] Thomas, G.W. (1996) Soil pH and Soil Acidity. In: Methods of Soil Analysis. Part 3, Chemical Method, SSSA, ASA, Madison, 475-490.

https://doi.org/10.2136/sssabookser5.3.c16

[15] Bremner, J.M. (1996) Nitrogen-Total. In: Methods of Soil Analysis. Part 3, Chemical Method, SSSA, ASA, Madison, 1085-1122.

https://doi.org/10.2136/sssabookser5.3.c37

[16] Walkley, A. and Black, I.A. (1934) An Examination of the Degtjareff Method for Determining Soil Organic Matter and a Proposed Modification of the Chromic Acid Titration Method. Soil Science, 37, 29-38. https://doi.org/10.1097/00010694-193401000-00003

[17] Nelson, D.W. and Sommers, L.E. (1996) Total Carbon, Organic Carbon, and Or- 
ganic Matter. In: Page, A.L., et al., Eds., Methods of Soil Analysis. Part 2. Agronomy Monographs 9, 2nd Edition, ASA and SSSA, Madison, 539-579. https://doi.org/10.2134/agronmonogr9.2.2ed.c29

[18] Bray, R.H. and Kurtz, L.T. (1965) Determination of Total, Organic, and Available Orms of Phosphorus in Soils. Soil Science, 59, 39-45. https://doi.org/10.1097/00010694-194501000-00006

[19] Kuo, S. (1996) Phosphorus in Methods of Soil Analysis. Part 3. Chemical Method. SSSA, WI and ASA, Madison, 869-919. https://doi.org/10.2136/sssabookser5.3.c32

[20] Thomas, G.W. (1982) Exchangeable Cations. In: Page, A.L., et al., Eds., Methods Soil Analysis. Part 2, Agronomy Monographs 9, 2nd Edition, ASA and SSSA, Madison, 159-165. https://doi.org/10.2134/agronmonogr9.2.2ed.c9

[21] Jones, J.B. (1998) Soil Test Methods: Past, Present, and Future Use of Soil Extractants. Communications in Soil Science and Plant Analysis, 29, 1543-1552. https://doi.org/10.1080/00103629809370048

[22] Page, A.L.P., Miller, R.H. and Keey, D.R. (1982) Method of Soil Analysis Part 2. 9th Edition, ASA, Madison.

[23] Black, C.A. (1986) Methods of Soil Analysis. Part I. Physical and Mineralogical Properties Including Statistics of Measurement and Samplings Part II. Chemical and Microbiological Properties. Agronomy Series. ASA, Madison.

[24] Sumner, M.E. and Miller, W.P. (1996) Cation Exchange Capacity and Exchange Coefficient in Methods of Soil Analysis. Part 3. Chemical Method. SSSA, ASA, Madison, 1185-1201. https://doi.org/10.2136/sssabookser5.3.c40

[25] Wears, J.I. and Sommer, A.L. (1948) Acid Extractable Zinc of Soils in Relation to Occurrence of Zinc Deficiency Symptoms of Corn: A Method of Analysis. Soil Science Society of America, Proceedings, 12, 143-144. https://doi.org/10.2136/sssaj1948.036159950012000C0031x

[26] Sally, L., Dave, C., Demie, M. and Teferi, T. (2008) Soil Science: Step-by-Step Field Analysis. Soil Science Society of America, Madison, 159-182.

[27] AOAC (Association of Official Analysis Chemists) (2005) Official Methods of Analysis. 18th Edition, Washington DC, 1-6.

[28] SAS (Statistical Analysis Software) (2002) Statistical Analysis Software Guide for Personal Computers. Release 9.1, SAS Institute Inc., Cary.

[29] Adepetu, J.A., Adetunji, M.T. and Ige, V. (2014) Soil Fertility and Crop Nutrition. Jumak Publishers, Ibadan, 106-470.

[30] Enwezor, W.O., Udo, E.J., Ayotade, K.A., Adepetu, J.A. and Chude, V.Q. (1990) A Review of Soil and Fertilizer Use Research in Nigeria. Federal Ministry of Agriculture, Water Resources and Rural Development, Lagos, 109-200.

[31] Michel, J., Weiske, A. and Moller, K. (2010) The Effect of Biogas Digestion on the Environmental Impact and Energy Balances in Organic Cropping Systems Using the Life Cycle Assessment Methodology. Renewable Agriculture and Food Systems, 25, 204. https://doi.org/10.1017/S1742170510000062

[32] Kurt, M. and Torsten, M. (2012) Effects of Anaerobic Digestion on Digestate Nutrient Availability and Crop Growth. A Review. Engineering in Life Sciences, 12, 242-257. https://doi.org/10.1002/elsc.201100085

[33] Adanikin, B.A. (2015) Biogass Production from Selected Water Weeds and the Nutrient Potential of Their Effluents for Crop Improvement. Unpublished M.Sc. Thesis, The Institute of Ecology and Environmental Studies, Obafemi Awolowo University, Ile-Ife, 67-70. 
[34] Adanikin, B.A., Adesanwo, O.O. and Ogunwande, G.A. (2017) Evaluation of Nutrient Potentials of Effluent from Biodigestion of Water Weed Species as Soil Ammendement. Ife Journal of Agriculture, 29, 39-46.

[35] Adeoluwa, O.O. and Akinyemi, O. (2014) Amaranthus (Amaranthus viridis) Dry Matter and Soil Qualities: Organic and Inorganic Fertilizer. Proceedings of the 4 th ISOFAR Scientific Conference Building Organic Bridges, Istanbul, 13-15 October 2014, 879-882.

[36] Lundvall, J.P., Lorimor, J.C., Sawyer, J.E., Barker, D.W. and Loria, E.R. (2007) Use of Anaerobically Digested Swine Manure as a Nitrogen Source in Corn Production. Agronomy Journal, 99, 1119-1129. https://doi.org/10.2134/agronj2006.0251

[37] Olatoberu, F.T., Idowu, M.K., Adepetu, J.A. and Akinremi, O.O. (2019) Differential Response of Biomass Production and Nitrogen Uptake of Vegetable Amaranth to Two Types of Poultry Manure from Nigeria and Canada. Food and Nutrition Sciences, 10, 694-711. https://doi.org/10.4236/fns.2019.106051

[38] Adebayo, A.A., Ewulo, B.S., Aiyelari, O.P. and Jiandong, H. (2021) Effects of NPK Fertilizer and Vine Care on Soil Chemical Properties and Cucumber (Cucumis sativus L.) Growth and Yield Parameters. International Journal of Plant \& Soil Science, 33, 136-151. https://doi.org/10.9734/ijpss/2021/v33i1830584 